\title{
Complete mitogenome of Olidiana ritcheriina (Hemiptera: Cicadellidae) and phylogeny of Cicadellidae
}

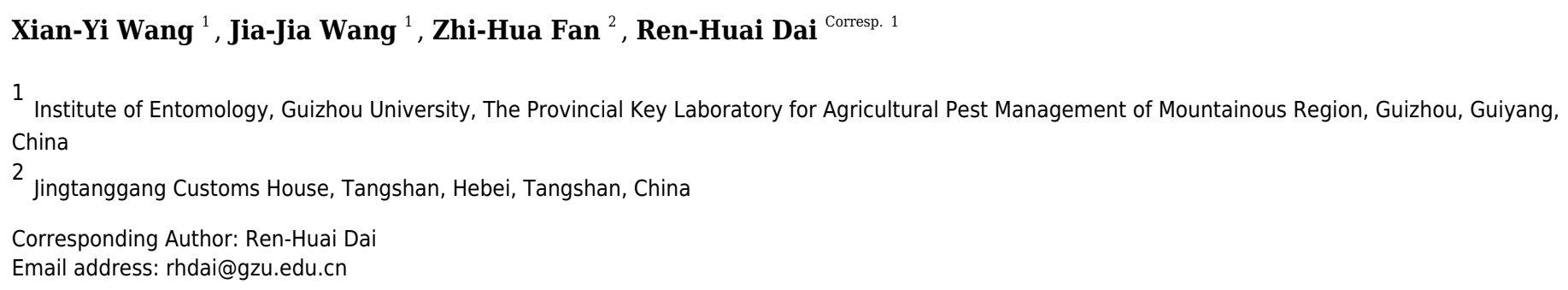

Background. Coelidiinae, a relatively large subfamily within the family Cicadellidae, includes 129 genera and 1,300 species distributed worldwide. However, the mitogenomes of only two species (Olidiana sp. and Taharana fasciana) in the subfamily Coelidiinae have been assembled. Here, we report the first complete mitogenome assembly of the genus Olidiana. Methods. Specimens were collected from Wenxian County (Gansu Province, China) and identified on the basis of their morphology. Mitogenomes were sequenced by next-generation sequencing, following which an NGS template was generated, and this was confirmed using polymerase chain reaction and Sanger sequencing. Phylogenic trees were constructed using maximum likelihood and Bayesian analyses. Results. The mitogenome of $O$. ritcheriina was 15,166 bp long, with an $A+T$ content of $78.0 \%$. Compared with the mitogenome of other Cicadellidae sp., the gene order, gene content, gene size, base composition, and codon usage of protein-coding genes (PCGs) in $O$. ritcheriina were highly conserved. The standard start codon of all PCGs was ATN and stop codon was TAA or TAG; COII, COIII, and ND4L ended with a single T. All tRNA genes showed the typical cloverleaf secondary structure, except for trnSer, which did not have the dihydrouridine arm. Furthermore, the secondary structures of rRNAs ( $r r n L$ and $r r n S$ ) in 0 . ritcheriina were predicted. Overall, 5 domains and 42 helices were predicted for $r r n L$ (domain III is absent in arthropods), and 3 structural domains and 27 helices were predicted for rrnS. Maximum likelihood and Bayesian analyses indicated that $O$. ritcheriina and other Coelidiinae members were clustered into a clade, indicating the relationships among their subfamilies; the main topology was as follows: (Deltocephalinae $+(($ Coelidiinae + lassinae $)+(($ Typhlocybinae + Cicadellinae $)+($ Idiocerinae + $($ Treehopper + Megophthalminae))))). The phylogenetic relationships indicated that the molecular taxonomy of $O$. ritcheriina is consistent with the current morphological classification. 
1 Complete mitogenome of Olidiana ritcheriina

2 (Hemiptera: Cicadellidae) and phylogeny of

3 Cicadellidae

4

5

6

7

8

Xian-Yi Wang ${ }^{1}$, Jia-Jia Wang ${ }^{1}$, Zhi-Hua Fan ${ }^{2}$, Ren-Huai Dai ${ }^{1}$

${ }^{1}$ Institute of Entomology, Guizhou University, The Provincial Key Laboratory for Agricultural

Pest Management of Mountainous Region, Guiyang, Guizhou, P. R. China

${ }^{2}$ Jingtanggang Customs House, Tangshan, 063611, Hebei, P. R. China

Corresponding Author:

Ren-Huai Dai ${ }^{1}$

Institute of Entomology, Guizhou University, The Provincial Key Laboratory for Agricultural Pest Management of Mountainous Region, Guiyang, Guizhou 550025, P. R. China Email address:1molbio@126.com

\section{Abstract}

Background. Coelidiinae, a relatively large subfamily within the family Cicadellidae, includes 129 genera and $\sim 1,300$ species distributed worldwide. However, the mitogenomes of only two species (Olidiana sp. and Taharana fasciana) in the subfamily Coelidiinae have been assembled. Here, we report the first complete mitogenome assembly of the genus Olidiana.

Methods. Specimens were collected from Wenxian County (Gansu Province, China) and identified on the basis of their morphology. Mitogenomes were sequenced by next-generation sequencing, following which an NGS template was generated, and this was confirmed using polymerase chain reaction and Sanger sequencing. Phylogenic trees were constructed using maximum likelihood and Bayesian analyses.

Results. The mitogenome of $O$. ritcheriina was 15,166 bp long, with an A $+\mathrm{T}$ content of $78.0 \%$. Compared with the mitogenome of other Cicadellidae sp., the gene order, gene content, gene size, base composition, and codon usage of protein-coding genes (PCGs) in O. ritcheriina were highly conserved. The standard start codon of all PCGs was ATN and stop codon was TAA or TAG; COII, COIII, and ND4L ended with a single T. All tRNA genes showed the typical cloverleaf secondary structure, except for trnSer, which did not have the dihydrouridine arm. Furthermore, the secondary structures of rRNAs ( $r r n L$ and $r r n S$ ) in $O$. ritcheriina were predicted. Overall, 5 domains and 42 helices were predicted for $r r n L$ (domain III is absent in arthropods), and 3 structural domains and 27 helices were predicted for $r r n S$. Maximum likelihood and Bayesian analyses indicated that $O$. ritcheriina and other Coelidiinae members were clustered into a clade, indicating the relationships among their subfamilies; the main topology was as follows: (Deltocephalinae $+(($ Coelidiinae + Iassinae $)+(($ Typhlocybinae + Cicadellinae $)+$ 
40 (Idiocerinae $+($ Treehopper + Megophthalminae $))))$ ). The phylogenetic relationships indicated

41 that the molecular taxonomy of $O$. ritcheriina is consistent with the current morphological

42 classification.

43 Subjects Biodiversity, Entomology, Evolutionary Studies, Genomics, Taxonomy

44 Key words Cicadellidae, Genomics, Mitogenome, Phylogenetics

45

46

47

48

49

50

51

52

53

54

55

56

57

58

59

60

61

62

63

64

65

66

67

68

69

70

71

72

73

74

75

76

77

78

79

\section{Introduction}

Coelidiinae is a relatively large subfamily within the Cicadellidae family, and it includes 129 genera and approximately 1,300 species (Nielson, 2015), including some species that serve as vectors of pathogens causing economically important plant diseases (Du et al., 2017; Frazier, 1975; Li \& Fan, 2017; Maramorosch, Harris \& Futuyma, 1981; Zhang, 1990). However, the taxonomic status of some species, on the basis of their morphology, remains controversial, and the phylogenetic relationships among major lineages of Membracoidea remain poorly understood (Dietrich et al., 2017). Moreover, knowledge regarding the taxonomic status of Olidiana within Cicadellidae and its phylogenetic relationship with other leafhopper genera is limited.

Complete mitogenomes provide large and diverse datasets for species delineation, and such mitogenomes have extensively been used for evolutionary studies of insects, particularly members of the orders Lepidoptera, Diptera, and Hemiptera (Salvato et al., 2008; Wang et al., 2011; Du et al., 2017; Su \& Liang, 2018; Wang et al., 2018; Li et al., 2017). To date, approximately 34 species (27 complete and 7 nearly complete) of the Cicadellidae mitogenome are available in GenBank. However, the mitogenomes of only two species [Olidiana sp. (partial genome, KY039119.1) and Taharana fasciana (NC_036015.1)] have previously been published for Coelidiinae, the largest subfamily of Cicadellidae.

Olidiana McKamey is the largest leafhopper genus in the tribe Coelidiini and it comprises 91 species. Among these, 54 species have been reported from China. However, to date, none of the characterized mitogenomes of the Olidiana sp. is complete; this lack of information restricts our understanding of the evolution of the Coelidiinae sp. at the genomic level. Therefore, new mitogenomic data will provide insights for determining the phylogenetic relationships and evolution of Cicadellidae in the future.

Olidiana ritcheriina, first described in 1990 (Zhang, 1990), is widely distributed throughout the Chinese provinces of Shaanxi, Hubei, Hunan, Guangdong, Hainan, Guangxi, Sichuan, Guizhou, and Yunnan. Therefore, a complete mitogenome of $O$. ritcheriina (GenBank accession NO.: MK738125) was sequenced to elucidate the phylogenetic status and relationships of the Coelidiinae sp.

\section{Materials \& Methods}

\section{Sample collection and identification}


80 The use of the specimens collected for this study was approved. The specimens were collected

81

82

83

84

85

86

87

88

89

90

91

92

93

94

95

96

97

98

99

100

101

102

103

104

105

106

107

108

109

110

111

112

113

114

115

116

117

118

119

from Wenxian County, Gansu Province, China $\left(32^{\circ} 95^{\prime} \mathrm{N}, 104^{\circ} 68^{\prime} \mathrm{E}\right)$ on October 17, 2018, and identified on the basis of their morphological characteristics, as described by Zhang (1990) and Li \& Fan (2017). Fresh specimens were preserved in absolute ethanol and stored at $-20^{\circ} \mathrm{C}$ until DNA extraction.

\section{DNA extraction}

Genomic DNA was extracted from the whole body of adult males (after removing the abdomen and wing) using DNeasy $\odot$ Tissue Kit (Qiagen, Hilden, Germany). The samples were incubated at $56^{\circ} \mathrm{C}$ for $6 \mathrm{~h}$ for completely lysing the cells, and total genomic DNA was eluted in $100 \mu \mathrm{L}$ of double-distilled water; the remaining steps were performed according to the manufacturer's instructions. The extracted genomic DNA was stored at $-20{ }^{\circ} \mathrm{C}$ until further use. Voucher specimens with male genitalia and DNA samples have been deposited at the Institute of Entomology, Guizhou University, Guiyang, China.

\section{Polymerase chain reaction (PCR) amplification and sequencing}

Mitogenomes were sequenced using next-generation sequencing (Illumina HiSeq 4000 and $2 \mathrm{~Gb}$ raw data; Berry Genomic, Beijing, China), and two sequence fragments were reconfirmed by PCR amplification using primers (Table S1). Following this, an NGS template was generated and this was further confirmed using PCR and Sanger sequencing. PCR amplification of overlapping sequence fragments was performed using universal primers (Table S1). Two pairs of speciesspecific primers were designed using Primer Premier 6.0 (Premier Biosoft, Palo Alto, CA, USA) to amplify the control region (Table S1). PCR was performed using a PCR master mix (Sangon Biotech Co. Ltd., Shanghai, China), according to the manufacturer's instructions.

\section{Sequence analysis}

Next-generation sequences were assembled using Geneious R9 (Kearse et al., 2012). The assembled mitochondrial gene sequences were compared with the homologous sequences of Olidiana sp. (KY039119) and T. fasciana (KY886913) retrieved from GenBank and identified through BLAST searches in NCBI to confirm sequence accuracy. The sequences obtained by PCR amplification and TA cloning were assembled using SeqMan in the DNAStar software package (DNASTAR, Inc., Madison, WI, USA). The mitogenomes were annotated using the MITOS webserver (Bernt et al., 2013). Base composition and relative synonymous codon usage (RSCU) were analyzed using MEGA 6.06 (Tamura et al., 2013), and the boundaries and secondary structures of 22 tRNA genes were determined using tRNAscan-SE version 1.21 (Schattner, Brooks \& Lowe, 2005) and ARWEN version 1.2 (Laslett \& Canbäck, 2008). rRNA genes were identified on the basis of the locations of adjacent tRNA genes and comparisons with sequences of other Hemipterans. The secondary structures of rRNAs were inferred on the basis of models proposed for other Hemiptera (Wang, Li \& Dai, 2017; Su et al., 2018). Helices were numbered according to the convention established by the Comparative RNA Web Site (Cannone 
120 et al., 2002). Strand asymmetry was calculated using the following formulas: AT skew $=(A-T)$

$121 /(\mathrm{A}+\mathrm{T}), \mathrm{GC}$ skew $=(\mathrm{G}-\mathrm{C}) /(\mathrm{G}+\mathrm{C})($ Perna \& Kocher, 1995). Intergenic spacers and

122 overlapping regions between genes were manually counted.

123

\section{Sequence alignment and phylogenetic analysis}

125

The phylogenetic analysis included complete or nearly complete mitogenome sequences of 42

126 insect species, namely 35 leafhoppers, 5 treehoppers, 2 froghoppers (Tettigades auropilosa and

127 Cosmoscarta bispecularis) as outgroups, and $O$. ritcheriina, which was newly sequenced (Table

128 1).

129

130

Each PCG and rRNA sequence was aligned using the MAFFT algorithm in Translator X (Abascal, Zardoya \& Telford, 2010; Katoh, Rozewicki \& Yamada, 2017) and MAFFT v7.0 online serve with the G-INS-i strategy (Castresana, 2000), respectively. Poorly aligned sites were removed using Gblocks $0.91 \mathrm{~b}$ (Castresana, 2000) under default settings, except that the gap sites were toggled as "none." Subsequently, the resulting 15 alignments were assessed and manually corrected using MEGA 6 (Tamura et al., 2013).

The following five datasets were concatenated for phylogenetic analysis: (1) P123: all codon positions of 13 PCGs (10,116 bp); (2) P12: first and second codon positions of 13 PCGs (6,744 bp); (3) P123-rR: P123 and two rRNAs (11,934 bp); (4) P12-rR: P12 and two rRNAs (8,562 bp); and (5) AA: amino acid sequences of 13 PCGs $(3,371 \mathrm{bp})$. The potential substitution saturation of four datasets (P123, P12, P123-rR, and P12-rR) was assessed using the index of substitution saturation (Iss) proposed by Xia et al. (2003) and implemented in DAMBE 5 (Xia, 2013). with the best model for each partition selected under the corrected Akaike Information Criterion (AIC) using PartitionFinder2 (Table S2) (Miller, Pfeiffer \& Schwartz, 2010) and evaluated using the ultrafast bootstrap approximation approach for 10,000 replicates. Bayesian (BI) analysis was performed using MrBayes 3.2 (Ronquist et al., 2012). Two independent runs with four simultaneous Markov chains (one cold and three incrementally heated at $\mathrm{T}=0.2$ ) were run for $50,000,000$ generations, sampling every 100 generations under the $\mathrm{GTR}+\mathrm{I}+\mathrm{G}$ model. The best models were then selected on the basis of the corrected AIC (Nylander et al., 2004). The phylogenetic trees were visualized using FigTree 1.4.2.

153

154

\section{Results}

\section{General features of the $O$. ritcheriina mitogenome} the range of the complete mitogenomes of other Cicadellidae sp. (Nephotettix cincticeps, 14,805 bp and Idioscopus laurifoliae, 16,811 bp) (Table 1). The mitogenome comprised 37 genes (13 
160

161

162

163

164

165

166

167

168

169

170

171

172

173

174

175

176

177

178

179

180

181

182

183

184

185

186

187

188

189

190

191

192

193

194

195

196

197

198

199

majority strand ( $\mathrm{J}$ strand) harbored most of the genes (9 PCGs and 14 tRNAs), whereas the minority strand (N strand) harbored the remaining genes (4 PCGs, 2 rRNAs, and 8 tRNAs) (Fig. 1; Table 2). Moreover, the mitogenome of O. ritcheriina comprised intergenic spacers of 1 to 12 bp long at nine different loci. A total of 12 gene pairs overlapped with one another, with overlap lengths ranging from 1 to $13 \mathrm{bp}$. In addition, 16 gene pairs, including $r r n L-t r n V$ and $t r n V-r r n S$ (Table 2), were directly adjacent to one another. With a multicopy of $\operatorname{trnI}$ (AAT) located

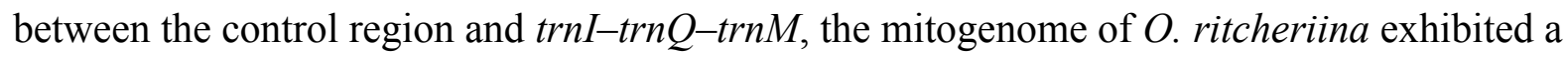
strong $\mathrm{A}+\mathrm{T}$ bias. The $\mathrm{A}+\mathrm{T}$ content of the whole genome was $78.0 \%$ (44.6\% A, 33.4\% T, 8.5\% $\mathrm{G}$, and $13.5 \% \mathrm{C}$ ) (Table 3); this percentage was between the $\mathrm{A}+\mathrm{T}$ content of Yanocephalus yanonis $(74.6 \%)$ and Trocnadella arisana $(80.7 \%)$ (Table 1$)$. The segment with the highest $\mathrm{A}+$ $\mathrm{T}$ content was present in the control region $(83.8 \%)$; the $\mathrm{A}+\mathrm{T}$ content of this segment was generally higher than that of other segments ( 2 rRNAs, $81.1 \%$; 22 tRNAs, 78.6\%; whole genome, 78.0\%; and 13 PCGs, 77.2\%) (Table 3).

Composition analysis revealed that the mitogenome of $O$. ritcheriina exhibited a positive AT (0.144) and negative GC skew $(-0.227)$ in the whole mitogenome as well as in the 13 PCGs (AT skew: 0.163; GC skew: -0.250), 2 rRNAs (AT skew: 0.160; GC skew: -0.265 ), and 22 tRNAs (AT skew: 0.111; GC skew: -0.110$)$. However, slightly negative AT $(-0.049)$ and GC $(-0.031)$ skews were detected in the control region (Table 3$)$.

Comparative analysis of the base composition of every component of the mitogenomes of Coelidiinae indicated that the control regions showed the highest $\mathrm{A}+\mathrm{T}$ content $(81.4 \%-83.8 \%)$ and that all species exhibited a positive AT $(0.144$ to 0.16$)$ or negative GC $(-0.227$ to -0.23$)$ skew (Wang, Li \& Dai, 2017) (Table 3).

\section{PCGs and codon usage}

The concatenated lengths of the 13 PCGs of $O$. ritcheriina were 10,116 nucleotide positions. Similar to the mitogenomes of other Cicadellidae sp., ND5 was the largest gene $(1,671 \mathrm{bp})$ and $A T P 8$ was the smallest gene (150 bp). Only four PCGs (ND4, ND4L, ND5, and ND1) were coded by the minority strand (N strand), whereas the other nine PCGs (COI, COII, COIII, ATP8, ATP6, $N D 2, N D 3, N D 6$, and $C Y T B$ ) were coded by the majority strand (J strand). Most PCGs exhibited the typical start codon ATN (ATA/ATT/ATG/ATC) and stop codon TAA or TAG, but COII, COIII, and ND4L showed an incomplete stop codon $\mathrm{T}$.

Analysis of the behavior of PCG codon families revealed an extremely similar codon usage among the mitogenomes of Cicadellidae, with TTA-Leu, ATA-Met, ATT-Ile, and TTT-Phe being the four most frequently used codons (Fig. 2A). Furthermore, the RSCU of $O$. ritcheriina indicated that degenerate codons were biased to use more $\mathrm{A} / \mathrm{T}$ than $\mathrm{G} / \mathrm{C}$ at the third codon (Fig. $2 B$ ). Similarly, the biased usage of $\mathrm{A}+\mathrm{T}$ nucleotides was reflected in the codon frequencies. 
200

201

202

203

204

205

206

207

208

209

210

211

212

213

214

215

216

217

218

219

220

221

222

223

224

225

226

227

228

229

230

231

232

233

234

235

236

237

238

239

\section{tRNAs and rRNAs}

All the 22 typical tRNA genes were present in the mitogenome of $O$. ritcheriina, and their lengths ranged between $61(\operatorname{trn} A$ and $\operatorname{trn} H)$ and $71 \mathrm{bp}(\operatorname{trnK})$. All tRNAs were identified using tRNAscan-SE (Schattner, Brooks \& Lowe, 2005) and ARWEN (Laslett \& Canbäck, 2008). Among these, 14 were located on the $J$ strand and 8 on the $N$ strand. All tRNAs exhibited the typical cloverleaf secondary structure, with the exception of trnS1 (AGN) in which the dihydrouridine arm formed a loop (Fig. 3). Abascal et al. $(2006 ; 2012)$ have shown that the invertebrate mitochondrial genetic code even shifts within the Hemiptera, with Triatoma (Cimicomorpha), Homalodisca (Cicadellidae), and Philaenus (Cercopoidea) using the AGG codon that was translated as Lys instead of Ser; accordingly, our tRNA analysis shows that the AGG codon in $O$. ritcheriina was translated as Lys instead of Ser.

Two rRNA genes ( $r r n L$ and $r r n S$ ) in the mitogenomes of Cicadellidae were highly conserved. The putative lengths of the $O$. ritcheriina genes $r r n L$ and $r r n S$ were 1,180 bp between $\operatorname{trnL} 2$ and trn $V$ and 731 bp between trnV and the control region, respectively (Tables 2 and 3). In the mitogenomes of Coelidiinae, the length of $r r n L$ ranged from 1,178 (Olidiana sp.) to 1,192 bp ( $T$. fasciana) and that of $r r n S$ ranged from 729 (Olidiana sp.) to $775 \mathrm{bp}$ (T. fasciana). The secondary structure of the $O$. ritcheriina gene $r r n L$ comprised five domains (I, II, IV, V, and VI; domain III is absent in arthropods) and 42 helices (Fig. 4). Multiple alignment of the Coelidiinae gene $r r n L$ extended over 1,180 positions and comprised 1,016 conserved (86.10\%) and 164 variable $(13.90 \%)$ sites. Domains IV and V were structurally more conserved than the other domains.

The secondary structure of $r r n S$ comprised three structural domains and 27 helices (Fig. 5). Multiple alignments of the Coelidiinae gene $r r n S$ extended over 730 positions and comprised 586 conserved $(80.23 \%)$ and 164 variable (19.73\%) sites. Domain III was structurally more conserved than domains I and II.

These rRNA secondary structures can be useful for the precise alignment of sequences for phylogenetic studies (Rijk \& Wachter, 1997). Nevertheless, additional details regarding such rRNA structures should be accumulated in future studies.

\section{Control region}

The control regions (A + T-rich regions) in the mitogenomes of Coelidiinae were not highly conserved, with lengths ranging between 915 (T. fasciana) and 1,069 bp (Olidiana sp.) and A + T content ranging between $77.9 \%$ (T. fasciana) and 78.1\% (Olidiana sp.) (Table 1). The length of the control region of $O$. ritcheriina was $981 \mathrm{bp}$, with a high $\mathrm{A}+\mathrm{T}$ content $(83.8 \%)$ and two repeats: R1 $(2 \times 49 \mathrm{bp})$ and $\mathrm{R} 2(2 \times 128 \mathrm{bp})($ Fig. $6 \mathrm{~A})$. However, the control regions of $T$. fasciana and Olidiana sp. comprised a single repeat (Fig. $6 \mathrm{~B}-\mathrm{C}$ ). In addition, the control region of the $O$. ritcheriina showed slightly negative AT $(-0.049)$ and GC $(-0.031)$ skews (Table 3). 


\section{Phylogenetic relationship}

241 Phylogenetic trees were constructed on the basis of five concatenated nucleotide sequence

242 datasets from 40 available mitogenomes of Membracoidea, with two species considered

243 outgroups [Cicadoidea (T. auropilosa) and Cercopoidea (C. bispecularis)]. Saturation analysis

244 addresses the issue on whether some positions or partitions of a dataset are saturated and to test

245 whether these sites can be used for further phylogenetic analysis. These phylogenetic trees

246 showed uncorrected pairwise divergence in transitions (s) and transversions (v) against

247 divergences calculated with the GTR model, and none of the four candidate nucleotide sequence

248 datasets (Fig. S1 A: P123; Fig. S1 B: P12; Fig. S1 C: P123-rR; Fig. S1 D: P12-rR) had reached

249 saturation (all Iss < Iss. cSym or Iss. cAsym, $p=0.0000$ ) (Table 4; Fig. S1), thereby suggesting

250 that the concatenated data is suitable for phylogenetic analysis.

251 All the 10 trees are presented in Fig. 7 and Fig. S2 A-F. Almost all nodes received high support

252

253

254

255

256

257

258

259

260

261

262

263

264

265

266

267

268

269

270

271

272

273

274

275

276

277

278

279

(posterior probability, $\mathrm{PP}>0.88$ ) in $\mathrm{BI}$ analyses, whereas a few nodes received only moderate or low support in ML analyses of some datasets (bootstrap support, BS $<75$ ). Monophyly at the subfamily level within Membracoidea was strongly supported in all the trees. Membracidae as a sister group to Cicadellidae was well supported by all the results $(\mathrm{PP}>0.94, \mathrm{BS}=100)$. Within Cicadellidae, the 37 species sampled in this study represent seven subfamilies and the main topology was as follows: (Deltocephalinae $+(($ Coelidiinae + Iassinae $)+(($ Typhlocybinae + Cicadellinae $)+($ Idiocerinae $+($ Treehopper + Megophthalminae) $))))($ Fig. 7). The results of BI and ML analyses generated results that are consistent with those of previous phylogenetic studies on the basis of combined morphological and molecular data (Dietrich et al., 2001; 2017; Cryan et al., 2000; 2012; Krishnankutty, 2013; Wang, Dietrich \& Zhang, 2017).

\section{Discussion}

The phylogenetic relationships inferred according to the five datasets showed slightly different topologies. In the BI-P123-rR/ML-P12-rR/ML-P123-rR analysis, the main topology was as follows: (Typhlocybinae $+($ Cicadellinae $+($ Deltocephalinae $+(($ Coelidiinae + Iassinae $)+$ (Idiocerinae + (Treehopper + Megophthalminae))))) $)($ Fig. S2 C). This topology is consistent with that reported in a previous study (Du et al., 2017) based on BI analysis of amino acid sequences. However, in some other studies (Du et al., 2017; Wang et al., 2018), the main topology has been reported to be different, i.e., (Deltocephalinae + (Typhlocybinae +

$($ Cicadellinae $+(($ Coelidiinae + Iassinae $)+($ Idiocerinae $+($ Treehopper + Megophthalminae $)))))$

(Fig. S2 D). This difference can be mainly attributed to the unstable positions of

Deltocephalinae, Typhlocybinae, and Coelidiinae and Iassinae (Fig. 7).

In Membracoidea, three clades exhibited a stable sister relationship as shown in all trees in the present analysis: Idiocerinae + (Typhlocybinae + Cicadellinae); Coelidiinae + Iassinae; and Treehopper + Megophthalminae. This result is consistent with that reported in some previous studies (Dietrich et al., 2001; 2017; Krishnankutty, 2013; Wang et al., 2017; 2018). Coelidiinae was the most closely related to Iassinae in the present study according to the $\mathrm{BI}(\mathrm{PP}=1.00)$ and

Peer) reviewing PDF | (2019:04:36782:3:0:NEW 6 Oct 2019) 
280

281

282

283

284

285

286

287

288

289

290

291

292

293

294

295

296

297

298

299

300

301

302

303

304

305

306

307

308

309

310

311

312

313

314

315

316

317

318

319

ML $(\mathrm{BS}=100)$ trees, which were the same as those reported in previous studies (Wang et al., 2017; 2018). Within Coelidiinae, the three species sampled in the present study represent Olidiana and Taharana. The inferred relationships (Taharana fascianus $+($ Olidiana $\mathrm{sp} .+$ Olidiana ritcheriina) ) were well supported by all BI $(\mathrm{PP}=1.00)$ and ML $(\mathrm{BS}=100)$ trees. The third codon position shows higher saturation than the first and second codon positions (Wei et al., 2010; Song et al., 2012) (Table S2). Nevertheless, in our phylogenetic results, tree topologies were consistent regardless of whether the third codon position was excluded; however, this exclusion slightly increased support for some nodes in ML analyses (ML-13PCGs12/ML13PCGs and ML-13PCGs12-2RNA/ML-13PCGs-2RNA) (Fig. S2 C, F). The results of the present study are consistent with those of a previous phylogenetic study (Du et al., 2017).

\section{Conclusions}

We sequenced the mitogenome of $O$. ritcheriina from Coelidiinae and presented their structure and sequence characteristics. Consistent with previous observations related to Membracoidea, the mitogenome of $O$. ritcheriina was highly conserved in terms of gene content, gene size, gene order, base composition, PCG codon usage, as well as tRNA and rRNA secondary structures.

Furthermore, the phylogeny of Membracoidea was inferred with all 40 complete mitogenomes, namely, 35 Cicadellidae and 5 Treehopper. The overall phylogenetic structure of Membracoidea is consistent with that reported in previous studies. Coelidiinae was grouped with a clade comprising Iassinae. The mitogenomic information of $O$. ritcheriina can be useful for future studies aimed at exploring the mitogenomic diversity of insects and evolution of related insect lineages.

The lack of complete mitogenomes of Coelidiinae sp. has restricted the understanding of the evolution of this group at the genome level. Therefore, further studies are required to elucidate the phylogenetic status of species belonging to this group and their relationships. In this context, the addition of more taxa and genes to the leafhopper mitogenomic dataset may contribute to the determination of the relationships shared among major leafhopper lineages.

\section{References}

Abascal F, Posada D, Knight RD, Zardoya R. 2006. Parallel evolution of the genetic code in arthropod mitochondrial genomes. PLoS Biology 4:711-718 DOI: 10.1371/journal.pbio.0040127.

Abascal F, Posada D, Zardoya R. 2012. The evolution of the mitochondrial genetic code in arthropods revisited. Mitochondrial DNA 23:84-91 DOI: http://dx.doi.org/10.3109/19401736.2011.653801.

Abascal F, Zardoya R, Telford JM. 2010. TranslatorX: multiple alignment of nucleotide sequences guided by amino acid translations. Nucleic acids research 38:7-13 DOI: $10.1093 /$ nar/gkq291. 
320 Bernt M, Donath A, Juehling F, Externbrink F, Florentz C, Fritzsch G, Puetz J,

321 Middendorf M, Stadler PF. 2013. MITOS: improved de novo metazoan mitochondrial genome 322 annotation. Molecular Phylogenetics and Evolution 69(2):313-319

323 DOI:10.1016/j.ympev.2012.08.023.

324 Cannone JJ,Subramanian S, Schnare MN, Collett JR, D'Souza LM, Du Y, Feng B, Lin N, 325 Madabusi LV, Müller KM, Pande N, Shang Z, Yu N, Gutell RR. 2002. The Comparative 326 RNA Web (CRW) Site: an online database of comparative sequence and structure information 327 for ribosomal, intron, and other RNAs. BMC Bioinformatics 3:2.

328 Castresana J. 2000. Selection of Conserved Blocks from Multiple Alignments for Their Use in 329 Phylogenetic Analysis. Molecular Biology and Evolution 17(4):540-552

330 DOI: 10.1093/oxfordjournals.molbev.a026334.

331 Choudhary JS, Naaz N, Das B, Bhatt BP, Prabhakar CS. 2018. Complete mitochondrial 332 genome of Idioscopus nitidulus (Hemiptera: Cicadellidae). Mitochondrial DNA B 3(1):191-192 333 DOI: 10.1080/23802359.2018.1437798.

334 Cryan JR, Urban J. 2012. Higher level phylogeny of the insect order Hemiptera: is 335 Auchenorrhyncha really paraphyletic? Systematic Entomology 37:7-21

336 DOI: 10.1111/j.1365-3113.2011.00611.x.

337 Cryan JR, Wiegmann BM, Deitz LL, Dietrich CH. 2000. Phylogeny of the treehoppers 338 (Insecta: Hemiptera: Membracidae): evidence from two nuclear genes. Molecular Phylogenetics 339 and Evolution 17(2):317-334 DOI: 10.1006/mpev.2000.0832.

340 Dai RH, Wang JJ, Yang MF. 2018. The complete mitochondrial genome of the leafhopper 341 Idioscopus clypealis (Hemiptera: Cicadellidae: Coelidiinae). Mitochondrial DNA B 3(1):32-33

342 DOI: 10.1080/23802359.2017.1419083.

343 Dietrich CH, Allen JM, Lemmon AR, Lemmon EM, Takiya DM, Evangelista O, Walden 344 KKO, Grady PGS, Johnson KP. 2017. Anchored hybrid enrichment-based phylogenomics of 345 leafhoppers and treehoppers (Hemiptera: Cicadomorpha: Membracoidea). Insect Systematics and 346 Diversity 1(1):57-72 DOI: 10.1093/isd/ixx003.

347 Dietrich CH, Rakitov RA, Holmes JL, Black IV WC. 2001. Phylogeny of the major lineages 348 of Membracoidea (Insecta: Hemiptera: Cicadomorpha) based on $28 S$ rDNA sequences.

349 Molecular Phylogenetics and Evolution 18(2):293-305 DOI: 10.1006/mpev.2000.0873.

350 Du Y, Zhang C, Dietrich CH, Zhang Y, Dai W. 2017. Characterization of the complete 351 mitochondrial genomes of Maiestas dorsalis and Japananus hyalinus (Hemiptera: Cicadellidae) 352 and comparison with other Membracoidea. Scientific Reports 7(1):14197

353 DOI: 10.1038/s41598-017-14703-3.

354 Du Y, Dai W, Dietrich CH. 2017. Mitochondrial genomic variation and phylogenetic 355 relationships of three groups in the genus Scaphoideus (Hemiptera: Cicadellidae:

356 Deltocephalinae). Scientific Reports 7(1):16908 DOI: 10.1038/s41598-017-17145-z.

357 Frazier NW. 1975. Possible transmission of strawberry pallidosis by the leafhopper Coelidia 358 olitoria. Plant Disease Reporter 59(1):40-41. 
359 Katoh K, Rozewicki J, Yamada KD. 2017. MAFFT online service: multiple sequence 360 alignment, interactive sequence choice and visualization. Briefings in Bioinformatics (4). 361 DOI: 10.1093/bib/bbx108.

362 Kearse M, Moir R, Wilson A, Stones-Havas S, Cheung M, Sturrock S, Buxton S, Cooper A, 363 Markowitz S, Duran C. 2012. Geneious basic: an integrated and extendable desktop software 364 platform for the organization and analysis of sequence data. Bioinformatics 28(12):1647-1649 365 DOI: 10.1093/bioinformatics/bts 199.

366 Krishnankutty S. 2013. Systematics and biogeography of leafhoppers in Madagascar.

367 Dissertations \& Theses - Gradworks 54(2290):666-674. DOI: 10.1016/j.sbspro.2012.09.784.

368 Laslett D, Canbäck B. 2008. ARWEN: a program to detect tRNA genes in metazoan

369 mitochondrial nucleotide sequences. Bioinformatics 24(2):172-175

370 DOI: $10.1093 /$ bioinformatics/btm573.

371 Li H, Leavengood JM, Chapman EG, Burkhardt D, Song F, Jiang P, Liu J, Zhou X, Cai

372 W. 2017. Mitochondrial phylogenomics of Hemiptera reveals adaptive innovations driving the 373 diversification of true bugs. Proceedings of the Royal Society B: Biological Sciences.

374 284(1862):20171223 DOI: 10.1098/rspb.2017.1223.

375 Li ZZ, Fan ZH. 2017. Coelidiinae (Hemiptera:Cicadellidae) from China. Guiyang: Guizhou 376 Science and Technology Press.

377 Liang AP, Gao J, Zhao X. 2016. Characterization of the complete mitochondrial genome of the

378

379

380

381

382

383

384

385

386

387

388

389

390

391

392

393

394

395

396 treehopper Darthula hardwickii (Hemiptera: Aetalionidae). DNA Sequence 27(5):2 DOI: $10.3109 / 19401736.2015 .1015008$.

Liu JH, Sun CY, Long J, Guo JJ. 2017. Complete mitogenome of tea green leafhopper, Empoasca onukii (Hemiptera: Cicadellidae) from Anshun, Guizhou Province in China. Mitochondrial DNA B 2(2):808-809 DOI: 10.1080/23802359.2017.1398616.

Mao M, Yang XS, Bennett G. 2016. The complete mitochondrial genome of Entylia carinata (Hemiptera: Membracidae). Mitochondrial DNA B 1(1):662-663

DOI: $10.1080 / 23802359.2016 .1219629$.

Mao M, Yang XS, Bennett G. 2017. The complete mitochondrial genome of Macrosteles quadrilineatus (Hemiptera: Cicadellidae). Mitochondrial DNA B 2(1):173-175 DOI: $10.1080 / 23802359.2017 .1303347$.

Maramorosch K, Harris KF, Futuyma DJ. 1981. Leafhopper Vectors and Plant Disease Agents. Netherlands Journal of Plant Pathology 87(4):129-130. DOI: 10.1007/BF01980406. Miller MA, Pfeiffer W, Schwartz T. 2010. "Creating the CIPRES Science Gateway for inference of large phylogenetic trees" in Proceedings of the Gateway Computing Environments Workshop (GCE), 14 Nov. 2010, New Orleans, LA pp 1-8. DOI: 10.1109/GCE.2010.5676129. Nylander JA, Ronquist F, Huelsenbeck JP, Nieves-Aldrey J. 2004. Bayesian phylogenetic analysis of combined data. Systematic Biology 53(1), 47-67

DOI: info:doi/10.1080/10635150490264699. 
397

398

399

400

401

402

403

404

405

406

407

408

409

410

411

412

413

414

415

416

417

418

419

420

421

422

423

424

425

426

427

428

429

430

431

432

433

434

Nguyen LT, Schmidt HA, von Haeseler A, Minh BQ. 2014. IQ-TREE: a fast and effective stochastic algorithm for estimating maximum-likelihood phylogenies. Molecular Biology and Evolution 32(1), 268-274 DOI: 10.1093/molbev/msu300.

Nielson MW. 2015. A revision of the tribe Coelidiini of the Oriental, Palearctic and Australian biogeographical regions (Hemiptera: Cicadellidae: Coelidiinae). Insecta Mundi 0410:1-202.

Perna NT, Kocher TD. 1995. Patterns of nucleotide composition at fourfold degenerate sites of animal mitochondrial genomes. Journal of Molecular Evolution 41(3):353-358

DOI: $10.1007 /$ BF00186547.

Rijk PD, Wachter RD. 1997. Rnaviz, a program for the visualisation of RNA secondary structure. Nucleic Acids Research 25(22):4679-4684 DOI: 10.1093/nar/25.22.4679.

\section{Ronquist F, Teslenko M, Van MP, Ayres DL, Darling A, Höhna S, Larget B, Liu L,}

Suchard MA, Huelsenbeck JP. 2012. MrBayes 3.2: efficient bayesian phylogenetic inference and model choice across a large model space. Systematic Biology 61:539-542 DOI: $10.1093 /$ sysbio/sys029.

Salvato P, Simonato M, Battisti A, \& Negrisolo E. 2008. The complete mitochondrial genome of the bag-shelter moth Ochrogaster lunifer (lepidoptera, notodontidae). BMC Genomics 9(1):331 DOI: 10.1186/1471-2164-9-331.

Schattner P, Brooks AN, Lowe TM. 2005. The tRNAscan-SE, snoscan and snoGPS web servers for the detection of tRNAs and snoRNAs. Nucleic Acids Research 33(Web Server issue):W686-W689 DOI: 10.1093/nar/gki366.

Song N, Cai WZ, Li H. 2017. Deep-level phylogeny of Cicadomorpha inferred from mitochondrial genomes sequenced by NGS. Scientific Reports 7(1):10429

DOI: $10.1038 / \mathrm{s} 41598-017-11132-0$.

Song N, Cai WZ, Li H. 2018. Insufficient power of mitogenomic data in resolving the auchenorrhynchan monophyly. Zoological Journal of the Linnean Society 183(4):776-790 DOI: 10.1093/zoolinnean/zlx096.

Song, N, Liang AP, Bu CP. 2012. A molecular phylogeny of hemiptera inferred from mitochondrial genome sequences. PLoS ONE 7(11):e48778 DOI: 10.1371/journal.pone.0048778.

Su TJ, He B, Li K, Liang AP. 2018. Comparative analysis of the mitochondrial genomes of oriental spittlebug trible cosmoscartini: insights into the relationships among closely related taxa. BMC Genomics 19(1):961 DOI: 10.1186/s12864-018-5365-7.

Su TJ, Liang AP. 2018. Characterization of the complete mitochondrial genome of Phymatostetha huangshanensis (Hemiptera: Cercopidae) and phylogenetic analysis.

International Journal of Biological Macromolecules 119:60-69

DOI: 10.1016/j.ijbiomac.2018.07.135.

Tamura K, Stecher G, Peterson D, Filipski A, Kumar S. 2013. MEGA6: molecular evolutionary genetics analysis version 6.0. Molecular Biology and Evolution 30(12): 2725-2729 
435 Wang JJ, Dai RH, Li H, Zhan HP. 2017. Characterization of the complete mitochondrial

436

437

438

439

440

441

442

443

444

445

446

447

448

449

450

451

452

453

454

455

456

457

458

459

460

461

462

463

464

465

466

467

468

469

470

471

472

473

genome of Japanagallia spinosa and Durgades nigropicta (Hemiptera: Cicadellidae:

Megophthalminae). Biochemical Systematics \& Ecology 74:33-41

DOI: $10.1016 /$ j.bse.2017.08.002.

Wang JJ, Li H, Dai RH. 2017. Complete mitochondrial genome of Taharana fasciana (Insecta, Hemiptera: Cicadellidae) and comparison with other Cicadellidae insects. Genetica 145(6):593602 DOI: 10.1007/s10709-017-9984-8.

Wang JJ, Yang MF, Dai RH, Li H, Wang XY. 2018. Characterization and phylogenetic implications of the complete mitochondrial genome of idiocerinae (Hemiptera: Cicadellidae). International Journal of Biological Macromolecules 120:2366-2372

DOI: 10.1016/j.ijbiomac.2018.08.191.

Wang S, Lei Z, Wang H, Dong B, Ren B. 2011. The complete mitochondrial genome of the leafminerliriomyza trifolii (diptera: agromyzidae). Molecular Biology Reports 38(2):687-692 DOI: $10.1007 / \mathrm{s} 11033-010-0155-6$.

Wang Y, Dietrich CH, Zhang Y. 2017. Phylogeny and historical biogeography of leafhopper subfamily Evacanthinae (Hemiptera: Cicadellidae) based on morphological and molecular data. Scientific Reports 7:45387 DOI: 10.1038/srep45387.

Wei SJ, Shi M, Sharkey MJ, Achterberg CV, Chen XX. 2010. Comparative mitogenomics of braconidae (insecta: hymenoptera) and the phylogenetic utility of mitochondrial genomes with special reference to holometabolous insects. BMC Genomics 11(1):371-0 DOI: 10.1186/1471-2164-11-371.

Wu YF, Dai RH, Zhan HP, Qu L. 2016. Complete mitochondrial genome of Drabescoides nuchalis (Hemiptera: Cicadellidae). Mitochondrial DNA A 27 (5):3626-3627 DOI: 10.3109/19401736.2015.1079827.

Xia X, Xie Z, Salemi M, Chen L, Wang Y. 2003. An index of substitution saturation and its application. Molecular Phylogenetics and Evolution 26(1):1-7

DOI: 10.1016/S1055-7903(02)00326-3.

Xia X. 2013. DAMBE5: a comprehensive software package for data analysis in molecular biology and evolution. Molecular Biology and Evolution 30(7):1720-1728

DOI: $10.1093 / \mathrm{molbev} / \mathrm{mst} 064$.

Yang H, Liu J Liang AP. 2016. The complete mitochondrial genome of Cosmoscarata bispecularis (Hemiptera, Cicadomorpha, Cercopoidea, Cercopidae). Mitochondrial DNA A 27(6):3957-3958 DOI: 10.3109/19401736.2014.989503.

Yu PF, Wang MX, Cui L, Chen XX, Han BY. 2017. The complete mitochondrial genome of Tambocerus sp. (Hemiptera: Cicadellidae). Mitochondrial DNA A 28 (1):133-134 DOI: $10.3109 / 19401736.2015 .1111357$.

Zhao X, Liang AP. 2016. Complete DNA sequence of the mitochondrial genome of the treehopper Leptobelus gazella (Membracoidea: Hemiptera). Mitochondrial DNA A 27 (5):33183319 DOI: 10.3109/19401736.2015.1018202.

Peer) reviewing PDF | (2019:04:36782:3:0:NEW 6 Oct 2019) 
474 Zhang YL.1990. A taxonomic study of Chinese Cicadellidae (Homoptera). Yang Ling: Tianze 475 Press.

476 Zhou N, Wang M, Cui L, Chen XX, Han BY. 2016. Complete mitochondrial genome of

477 Empoasca vitis (Hemiptera: Cicadellidae). Mitochondrial DNA A 27(2):1052-1053

478 DOI: 10.3109/19401736.2014.928863. 
Figure 1

Circular map of the Olidiana ritcheriina mitochondrial genome. Protein coding and ribosomal genes are shown with standard abbreviations. Transfer RNA (tRNA) genes are indicated using the IUPAC-IUB single letter amino acid codes (L1: CUN; L2: UUR; S2

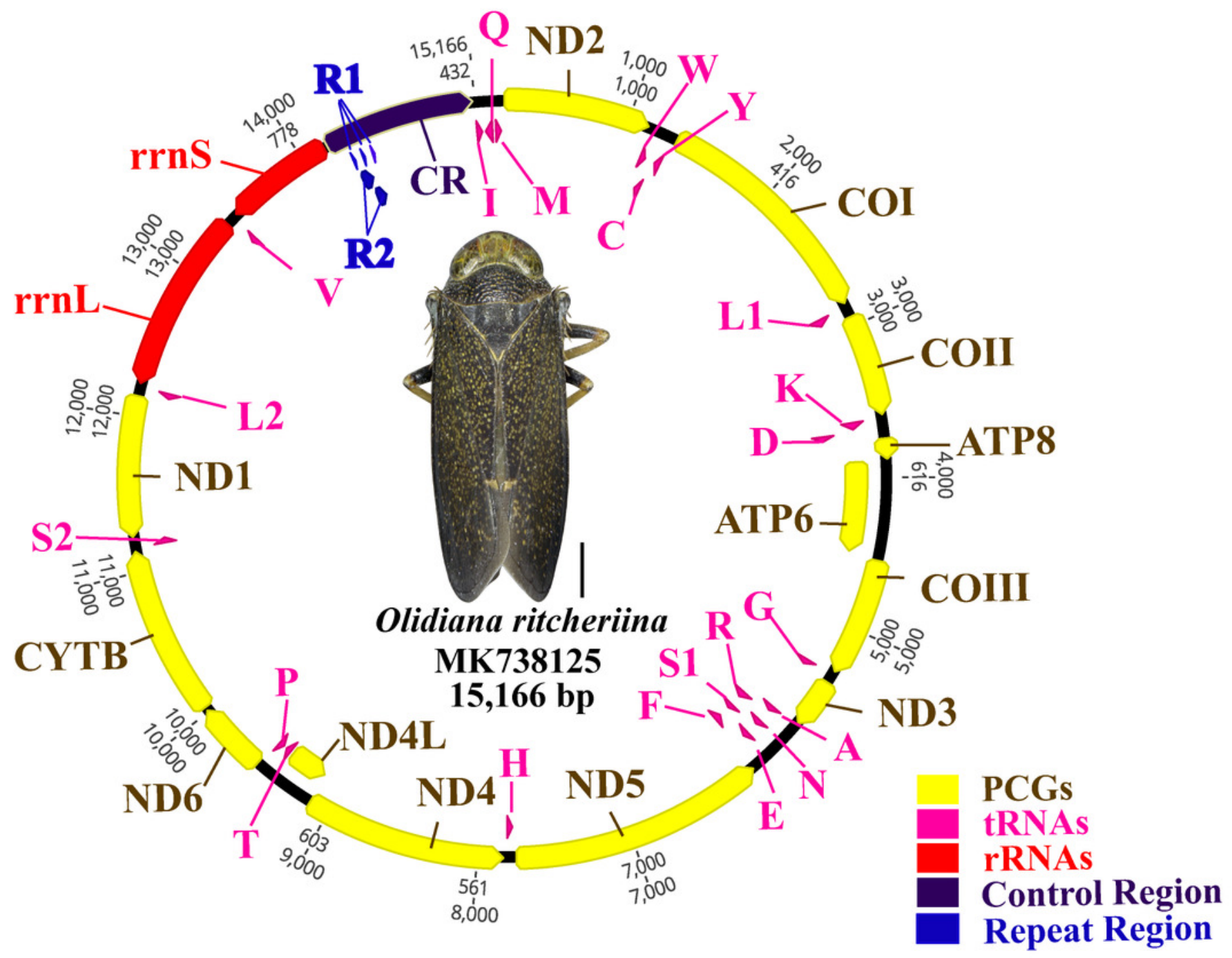


Figure 2

The codon number and relative synonymous codon usage (RSCU) of PCGs in Olidiana ritcheriina mitogenome. 


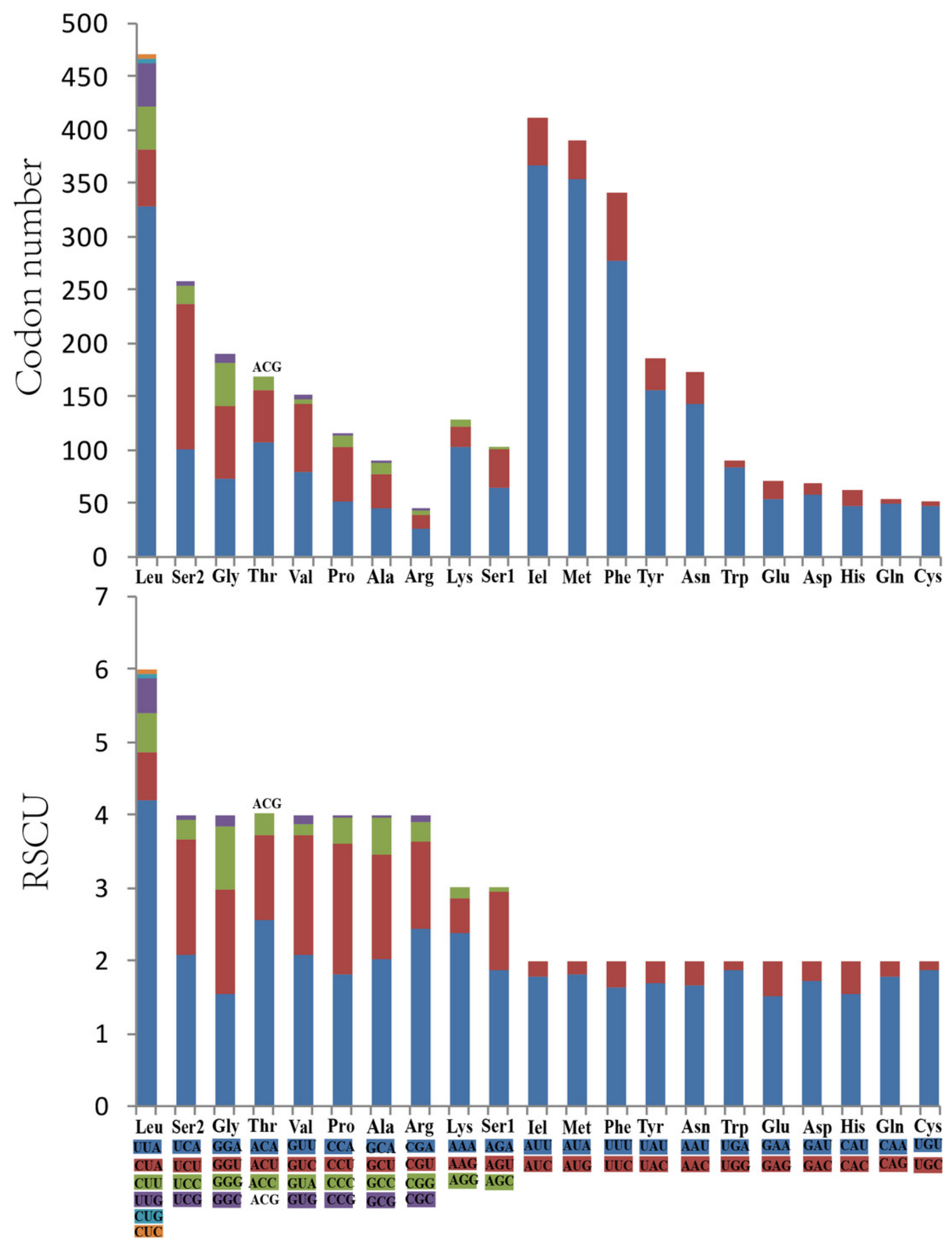


Figure 3

Secondary structures of tRNAs in the mitogenome of Olidiana ritcheriina. The dashes indicate Watson-Crick bonds and GU pairs, solid dots indicate mismatches. 

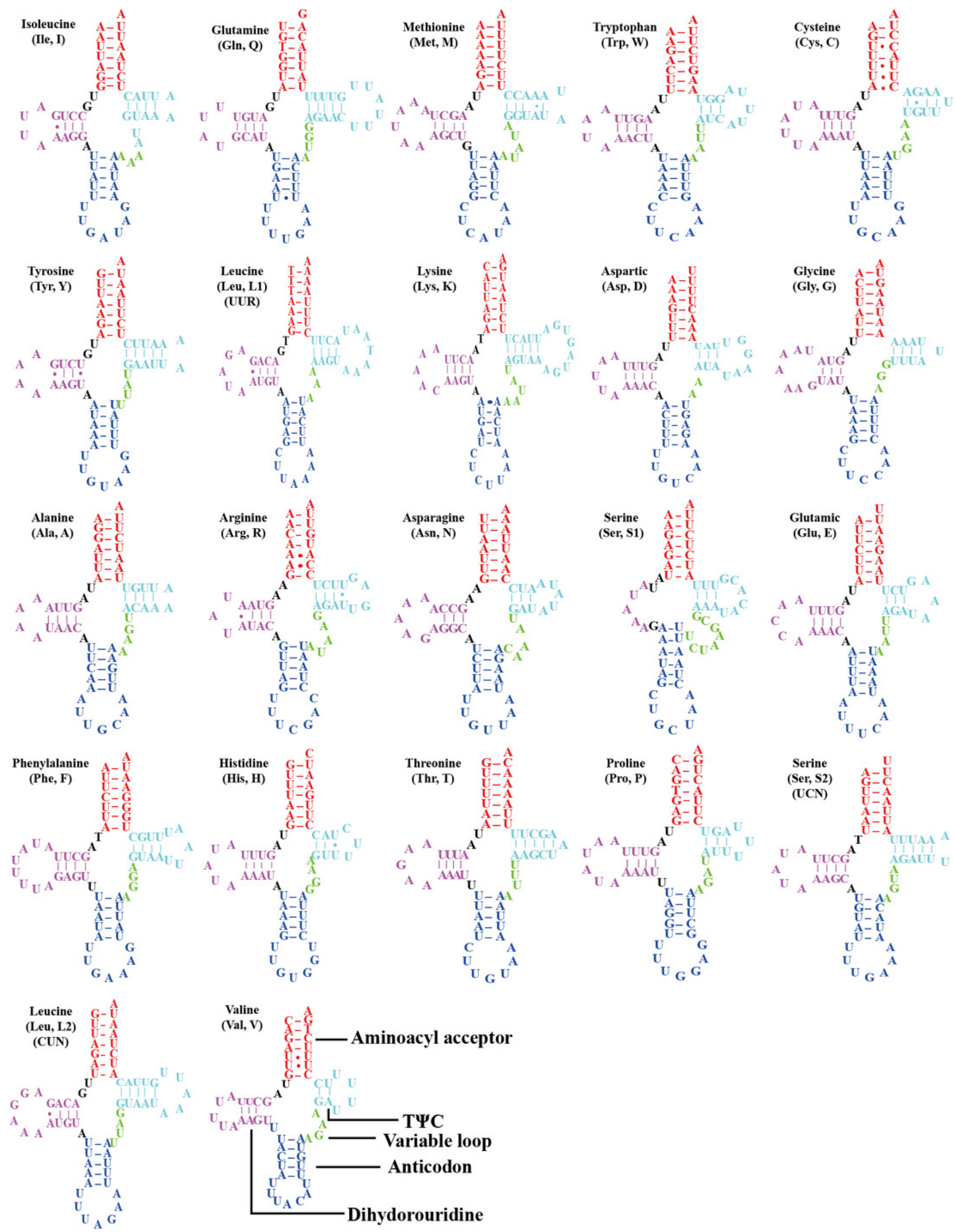

Peer] reviewing PDF | (2019:04:36782:3:0:NEW 6 Oct 2019) 


\section{Figure 4}

Predicted secondary structure of the $r r n L$ in the mitogenome of Olidiana ritcheriina. Roman numerals indicate the conserved domain structure. Watson-Crick pairs are joined by dashes, hereas GU pairs are connected by dots.

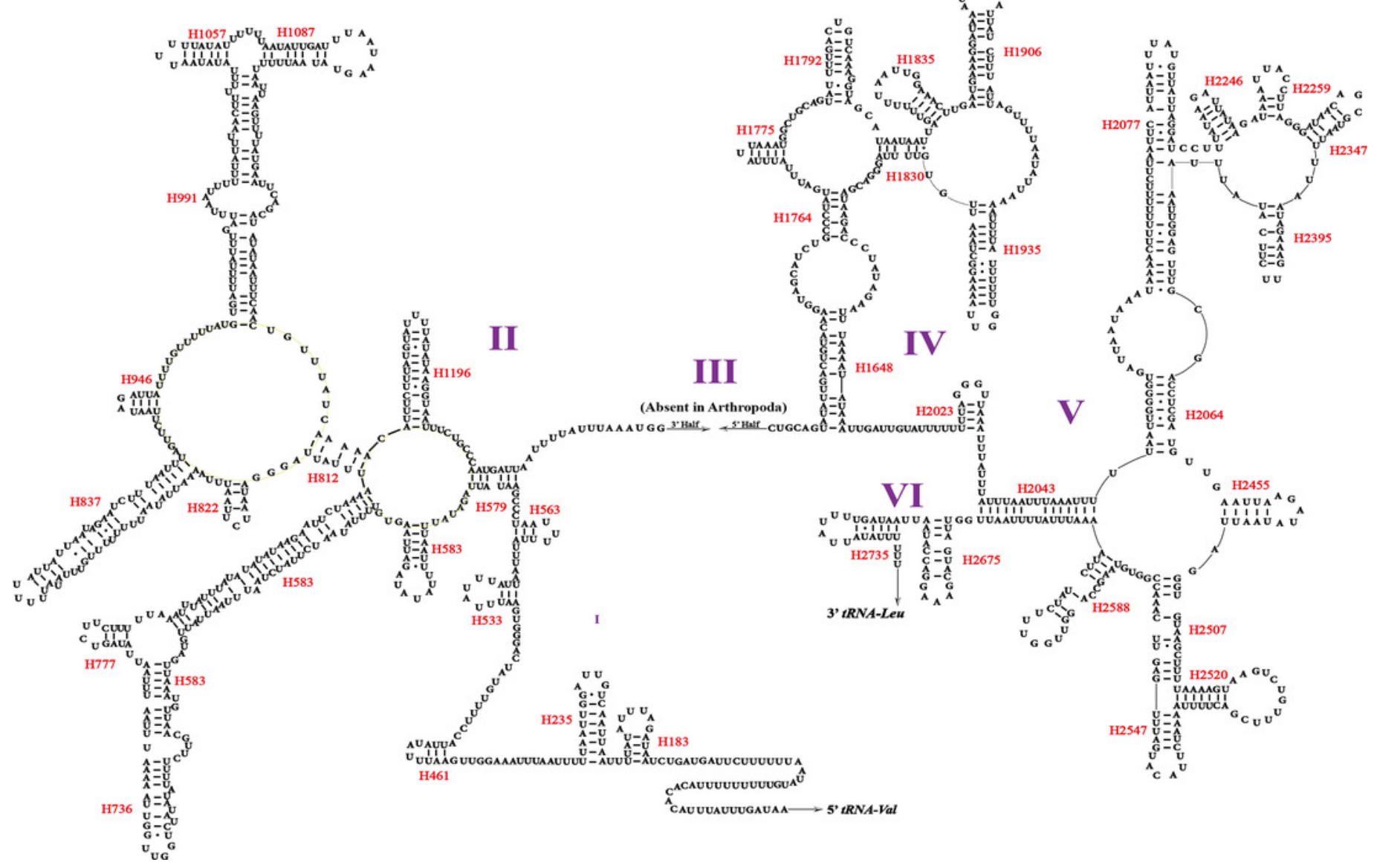




\section{Figure 5}

Predicted secondary structure of the rrnS in the mitogenome of Olidiana ritcheriina. Roman numerals indicate the conserved domain structure. Watson-Crick pairs are joined by dashes, hereas GU pairs are connected by dots.

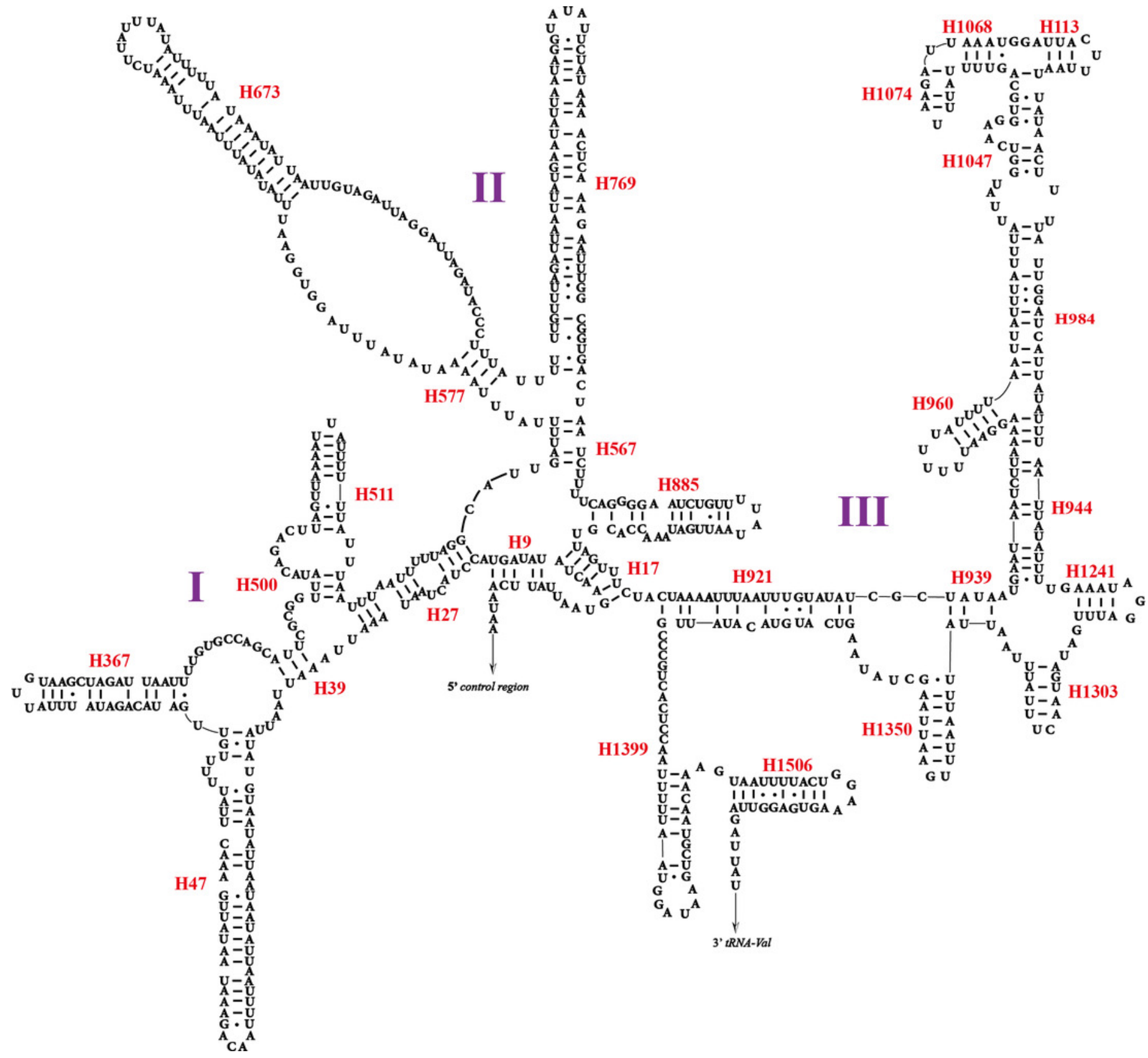


Figure 6

Organization of the control region structure in the mitochondrial genomes of Olidiana ritcheriina. R: repeat unit.

\section{Olidiana ritcheriina}

R1

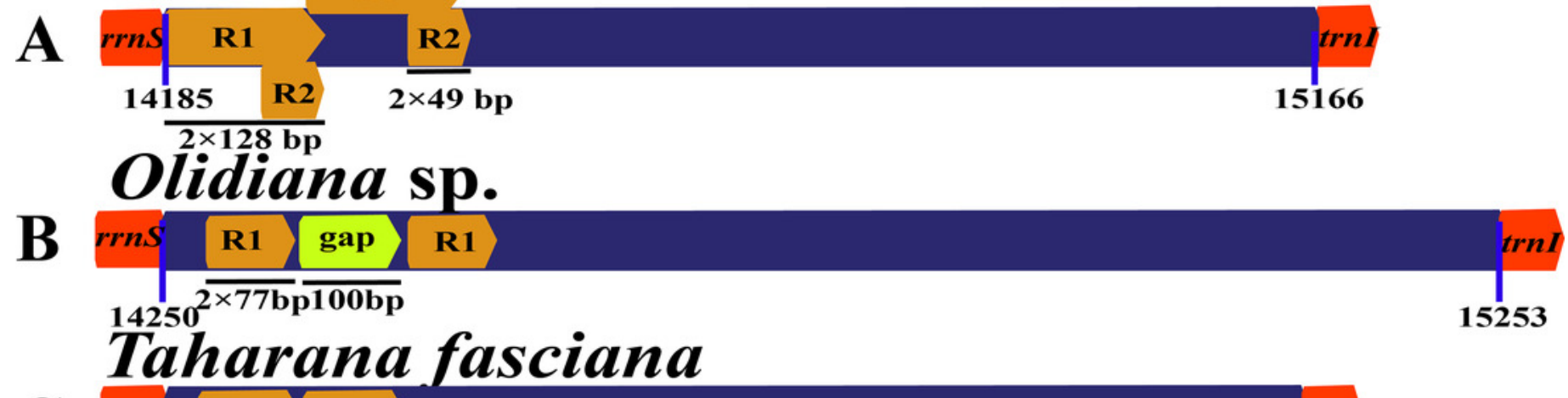

C

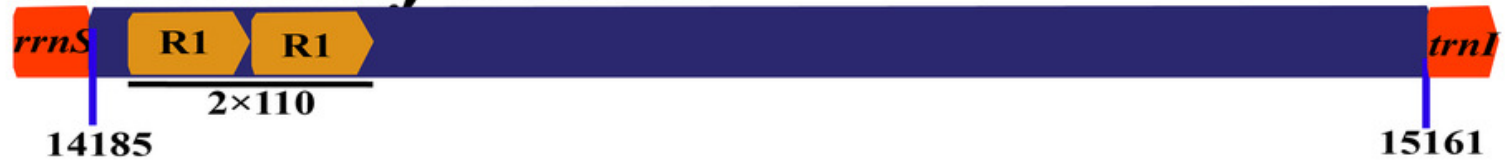


Figure 7

Phylogenetic trees of Olidiana ritcheriina inferred based on the first and second codon positions of 13 PCGs using GTR+I+G model in MrBayes.

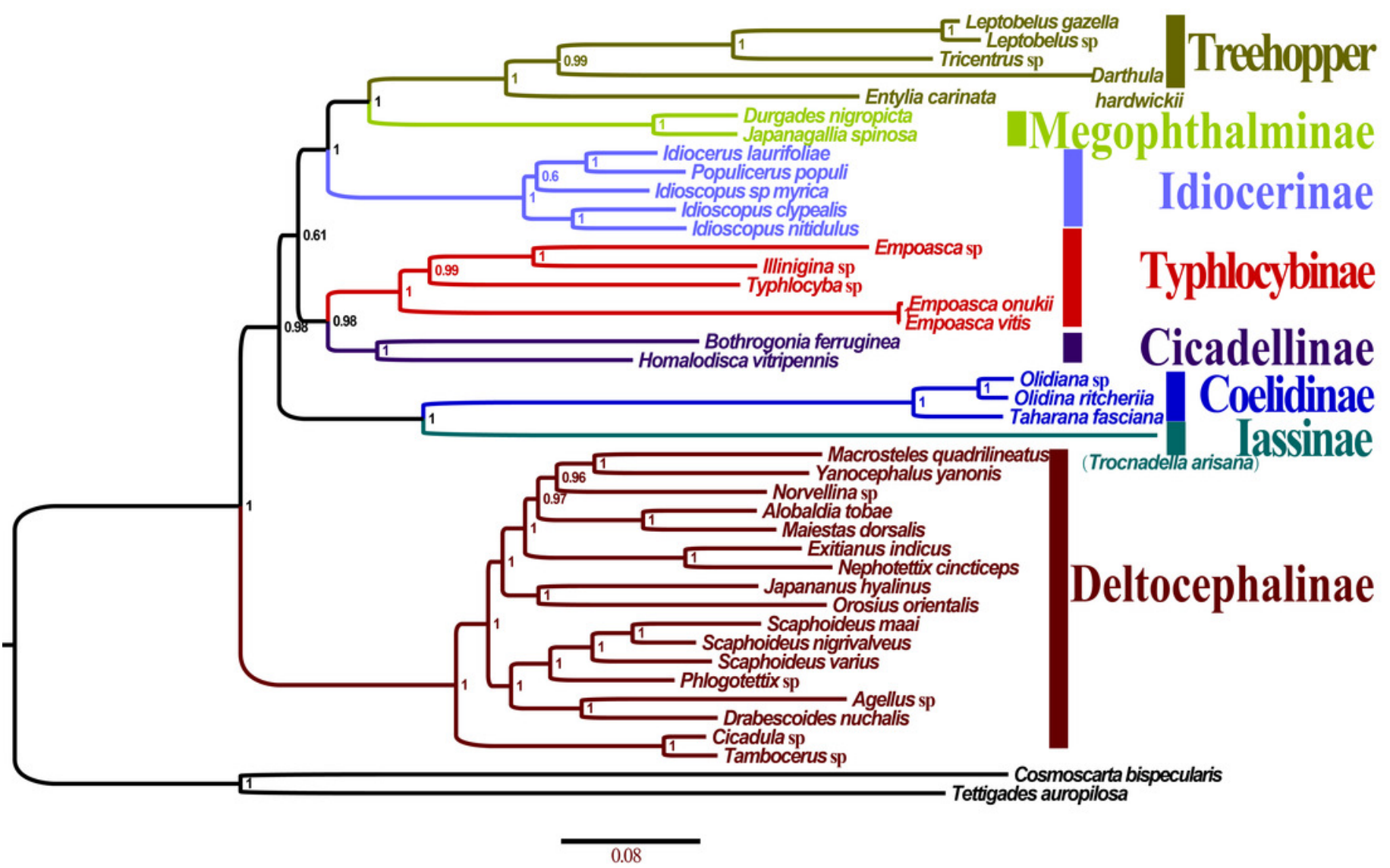




\section{Table 1 (on next page)}

Summary of the mitogenomes used in this study. 
1

\begin{tabular}{|c|c|c|c|c|c|}
\hline & Species & $\begin{array}{l}\text { Size } \\
\text { (bp) }\end{array}$ & $\begin{array}{l}\mathrm{A}+\mathrm{T} \\
(\%)\end{array}$ & $\begin{array}{l}\text { Accession } \\
\text { number }\end{array}$ & Reference \\
\hline \multirow[t]{2}{*}{ Cicadellinae } & $\begin{array}{l}\text { Bothrogonia } \\
\text { ferruginea }\end{array}$ & 15,262 & $\begin{array}{l}76 . \\
5\end{array}$ & $\begin{array}{l}\text { KU16755 } \\
0\end{array}$ & Unpublished \\
\hline & $\begin{array}{l}\text { Homalodisca } \\
\text { vitripennis }\end{array}$ & 15,304 & $\begin{array}{l}78 . \\
4\end{array}$ & $\begin{array}{l}\text { NC_00689 } \\
9\end{array}$ & Unpublished \\
\hline \multirow[t]{3}{*}{$\begin{array}{l}\text { Coelidiina } \\
\text { e }\end{array}$} & Olidiana ritcheriina & 15,166 & $\begin{array}{l}78 . \\
0\end{array}$ & $\begin{array}{l}\text { MK73812 } \\
5\end{array}$ & This study \\
\hline & Olidiana sp. ${ }^{\mathrm{a}}$ & 15,253 & $\begin{array}{l}78 . \\
1\end{array}$ & $\begin{array}{l}\text { KY03911 } \\
9\end{array}$ & Unpublished \\
\hline & Taharana fasciana & 15,161 & 77.9 & $\begin{array}{l}\text { KY88691 } \\
3\end{array}$ & $\begin{array}{l}\text { Wang, Li \& Dai } \\
\text { (2017) }\end{array}$ \\
\hline \multirow[t]{14}{*}{$\begin{array}{l}\text { Deltoceph } \\
\text { alinae }\end{array}$} & Agellus sp. ${ }^{\text {a }}$ & 14,819 & 75.8 & KX437738 & $\begin{array}{l}\text { Song, Cai \& Li } \\
(2018)\end{array}$ \\
\hline & Alobaldia tobae & $\begin{array}{l}16,02 \\
6\end{array}$ & $\begin{array}{l}77 . \\
3\end{array}$ & $\begin{array}{l}\text { KY03911 } \\
6\end{array}$ & $\begin{array}{l}\text { Song, Cai \& Li } \\
\text { (2017) }\end{array}$ \\
\hline & Cicadula sp. ${ }^{\mathrm{a}}$ & $\begin{array}{l}14,92 \\
9\end{array}$ & $\begin{array}{l}74 . \\
1\end{array}$ & $\begin{array}{l}\mathrm{KX} 43772 \\
4\end{array}$ & $\begin{array}{l}\text { Song, Cai \& Li } \\
\text { (2018) }\end{array}$ \\
\hline & Drabescoides nuchalis & 15,309 & $\begin{array}{l}75 . \\
6\end{array}$ & $\mathrm{NC} \_028154$ & Wu et al. (2016) \\
\hline & Exitianus indicus ${ }^{\text {a }}$ & 16,089 & $\begin{array}{l}75 . \\
1\end{array}$ & $\begin{array}{l}\text { KY03912 } \\
8\end{array}$ & $\begin{array}{l}\text { Song, Cai \& Li } \\
\text { (2017) }\end{array}$ \\
\hline & Japananus hyalinus & 15,364 & $\begin{array}{l}76 . \\
6\end{array}$ & $\begin{array}{l}\text { NC_03629 } \\
8\end{array}$ & Du et al, 2017 \\
\hline & $\begin{array}{l}\text { Macrosteles } \\
\text { quadrilineatus }\end{array}$ & 16,626 & $\begin{array}{l}78 . \\
0\end{array}$ & $\begin{array}{l}\text { NC_03478 } \\
1\end{array}$ & $\begin{array}{l}\text { Mao, Yang \& } \\
\text { Bennett (2017) }\end{array}$ \\
\hline & Maiestas dorsalis & 15,352 & $\begin{array}{l}78 . \\
7\end{array}$ & $\begin{array}{l}\text { NC_03629 } \\
6\end{array}$ & Du et al. (2017) \\
\hline & Nephotettix cincticeps & 14805 & $\begin{array}{l}77 . \\
6\end{array}$ & $\begin{array}{l}\text { NC_02697 } \\
7\end{array}$ & Unpublished \\
\hline & Norvellina sp. ${ }^{\mathrm{a}}$ & 15,594 & $\begin{array}{l}74 . \\
5\end{array}$ & $\begin{array}{l}\text { KY03913 } \\
1\end{array}$ & $\begin{array}{l}\text { Song, Cai \& Li } \\
\text { (2017) }\end{array}$ \\
\hline & Orosius orientalis a & 15,513 & $\begin{array}{l}72 . \\
0\end{array}$ & $\begin{array}{l}\text { KY03914 } \\
6\end{array}$ & $\begin{array}{l}\text { Song, Cai \& Li } \\
\text { (2017) }\end{array}$ \\
\hline & Phlogotettix sp. & 15,136 & $\begin{array}{l}77 . \\
9\end{array}$ & $\begin{array}{l}\text { KY03913 } \\
5\end{array}$ & $\begin{array}{l}\text { Song, Cai \& Li } \\
(2017)\end{array}$ \\
\hline & Scaphoideus maai & 15,188 & $\begin{array}{l}77 . \\
2\end{array}$ & $\begin{array}{l}\text { KY81724 } \\
3\end{array}$ & $\begin{array}{l}\text { Du, Dai \& } \\
\text { Dietrich (2017) }\end{array}$ \\
\hline & Scaphoideus & 15,235 & 76. & KY81724 & Du, Dai \& \\
\hline
\end{tabular}




\begin{tabular}{|c|c|c|c|c|c|}
\hline & nigrivalveus & & 6 & 4 & Dietrich (2017) \\
\hline & Scaphoideus varius & 15007 & 75. & KY81724 & Du, Dai \& \\
\hline & & IJ, & 9 & 5 & Dietrich (2017) \\
\hline & Tambocerus sp. & 15055 & 76. & KT827824 & Yu et al. (2017) \\
\hline & & כניר, & 4 & & \\
\hline & Yanocephalus & 15623 & 74. & NC_03613 & Song, Cai \& Li \\
\hline & yanonis & $15,0<5$ & 6 & 1 & $(2017)$ \\
\hline Iassinae & Trocnadella arisana & 15131 & 80. & NC_03648 & Unpublished \\
\hline & & 1 & 7 & 0 & \\
\hline Idiocerin & Idioscopus clypealis & 15303 & 78. & MF78443 & Dai, Wang \& \\
\hline ae & & נונכתו & 3 & 0 & Yang (2018) \\
\hline & Idioscopus laurifoliae & 16811 & 79. & MH43362 & Wang et al. (2018) \\
\hline & & 10,011 & 5 & 2 & \\
\hline & Idioscopus sp myrica & 15423 & 77. & MH49231 & Wang et al. (2018) \\
\hline & & 15,425 & 9 & 7 & \\
\hline & Idioscopus nitidulus & 15287 & 78. & NC_02920 & Choudhary et al. \\
\hline & & 15,201 & 6 & 3 & $(2018)$ \\
\hline & Populicerus populi & 16104 & 77. & MH49231 & Wang et al. (2018) \\
\hline & & 10,494 & 2 & 8 & \\
\hline Megophthal & Durgades nigropicta & & 78. & NC_03568 & Wang et al. (2017) \\
\hline minae & & 15,4 & 8 & 4 & \\
\hline & Japanagallia spinosa & 15655 & 76. & NC_03568 & Wang et al. (2017) \\
\hline & & נינס, & 6 & 5 & \\
\hline Treehopper & Darthula_hardwickii & 15255 & 78. & NC_02669 & Liang, Gao \& \\
\hline & & נככ, & 0 & 9 & Zhao (2016) \\
\hline & Entylia carinata & 15662 & 78. & NC_03353 & Mao, Yang \& \\
\hline & & 15,002 & 1 & 9 & Bennett (2016) \\
\hline & Leptobelus gazella & 16007 & 78. & NC_02321 & Zhao \& Liang \\
\hline & & 10,007 & 8 & 9 & $(2017)$ \\
\hline & Leptobelus sp. & 15201 & 77. & JQ910984 & Li et al. (2017) \\
\hline & & $1 J, \angle 01$ & 5 & & \\
\hline & Tricentrus sp. & 15.410 & 78. & KY03911 & Unpublished \\
\hline & & 15,419 & 5 & 8 & \\
\hline Typhlocybin & Empoasca onukii & 15167 & 78. & NC_03721 & Liu et al. (2017) \\
\hline ae & & I & 3 & 0 & \\
\hline & Empoasca sp. ${ }^{\mathrm{a}}$ & 15,116 & 76. & KX43773 & Song, Cai \& Li \\
\hline & & & 8 & 7 & (2018) \\
\hline & Empoasca vitis & 15154 & 78. & NC_02483 & Zhou et al. (2017) \\
\hline & & & 3 & 8 & \\
\hline & Illinigina $\mathrm{sp} .{ }^{\mathrm{a}}$ & 14,803 & 76. & KY03912 & Song, Cai \& Li, \\
\hline
\end{tabular}




\begin{tabular}{llllll}
\hline & & 0 & 9 & $(2017)$ \\
& Typhlocyba sp. & 15,223 & 77. & KY03913 & Song, Cai \& Li \\
& & 1 & 8 & $(2017)$ \\
Cicadoidea & Tettigades auropilosa & 14,944 & 75. & KM000129 & Unpublished \\
& & & 0 & & \\
Cercopoid & Cosmoscarta & 15,426 & 78. & KP064511 & Yang, Liu \& \\
ea & bispecularis & & 5 & & Liang (2016) \\
\hline
\end{tabular}

2 a Incomplete mitochondrial genomes.

3 
Table 2 (on next page)

Composition and skewness of the Olidiana ritcheriina mitogenome. 
1

\begin{tabular}{|c|c|c|c|c|c|c|c|}
\hline Gene & Direction & Location & $\begin{array}{l}\text { Size } \\
\text { (bp) }\end{array}$ & Start & Stop & Anticodon & $\begin{array}{l}\text { Intergenic } \\
\text { nucleotides }\end{array}$ \\
\hline trnI & $\mathrm{J}$ & $1-62$ & 62 & - & - & GAT & \\
\hline $\operatorname{trn} Q$ & $\mathrm{~N}$ & $64-130$ & 67 & - & - & TTG & 1 \\
\hline $\operatorname{trn} M$ & $\mathrm{~J}$ & $131-196$ & 66 & - & - & CAT & 0 \\
\hline ND2 & $J$ & $197-1,153$ & 957 & ATT & TAA & - & 0 \\
\hline $\operatorname{trn} W$ & $J$ & $1,152-1,213$ & 62 & - & - & TCA & 2 \\
\hline $\operatorname{trn} C$ & $\mathrm{~N}$ & $1,201-1,262$ & 62 & - & - & GCA & -13 \\
\hline $\operatorname{trn} Y$ & $\mathrm{~N}$ & $1,263-1,325$ & 63 & - & - & GTA & 0 \\
\hline $\mathrm{COI}$ & $\mathrm{J}$ & $1,338-2,873$ & 1,536 & ATG & TAA & - & 12 \\
\hline $\operatorname{trnL1}(U U R)$ & $\mathrm{J}$ & $2,874-2,940$ & 67 & - & - & TAA & 0 \\
\hline COII & $\mathrm{J}$ & $2,941-3,616$ & 676 & ATT & $\mathrm{T}$ & - & 0 \\
\hline $\operatorname{trn} K$ & $\mathrm{~J}$ & $3,617-3,687$ & 73 & - & - & CTT & 0 \\
\hline $\operatorname{trn} D$ & $\mathrm{~J}$ & $3,687-3,748$ & 62 & - & - & GTC & -1 \\
\hline ATP8 & $\mathrm{J}$ & $3,750-3,899$ & 150 & ATA & TAA & - & 1 \\
\hline ATP6 & $\mathrm{J}$ & $3,893-4,537$ & 645 & ATG & TAA & - & -7 \\
\hline COIII & $\mathrm{J}$ & $4,538-5,315$ & 778 & ATG & $\mathrm{T}$ & - & 0 \\
\hline $\operatorname{trn} G$ & $\mathrm{~J}$ & $5,316-5,375$ & 60 & - & - & TCC & 0 \\
\hline ND3 & $\mathrm{J}$ & $5,376-5,729$ & 354 & ATA & TAG & - & 0 \\
\hline $\operatorname{trn} A$ & $\mathrm{~J}$ & $5,728-5,788$ & 61 & - & - & TGC & -2 \\
\hline $\operatorname{trn} R$ & $\mathrm{~J}$ & $5,788-5,852$ & 65 & - & - & TCG & -1 \\
\hline $\operatorname{trn} N$ & $\mathrm{~J}$ & $5,850-5,913$ & 64 & - & - & GTT & -3 \\
\hline $\operatorname{trnS1}(A G N)$ & $\mathrm{J}$ & $5,913-5,974$ & 62 & - & - & GCT & -1 \\
\hline $\operatorname{trn} E$ & $\mathrm{~J}$ & $5,974-6,036$ & 63 & - & - & TTC & -1 \\
\hline $\operatorname{trn} F$ & $\mathrm{~N}$ & $6,036-6,103$ & 68 & - & - & GAA & -1 \\
\hline
\end{tabular}




\begin{tabular}{|c|c|c|c|c|c|c|c|}
\hline ND5 & $\mathrm{N}$ & $6,103-7,773$ & 1,671 & ATA & TAG & - & -1 \\
\hline $\operatorname{trn} H$ & $\mathrm{~N}$ & $7,774-7,834$ & 61 & - & - & GTG & 0 \\
\hline ND4 & $\mathrm{N}$ & $7,834-9,150$ & 1,317 & ATG & TAG & - & -1 \\
\hline ND4L & $\mathrm{N}$ & $9,152-9,419$ & 278 & ATG & $\mathrm{T}$ & - & 1 \\
\hline $\operatorname{trn} T$ & $\mathrm{~J}$ & $9,422-9,484$ & 63 & - & - & TGT & 1 \\
\hline $\operatorname{trn} P$ & $\mathrm{~N}$ & $9,485-9,546$ & 62 & - & - & TGG & 0 \\
\hline ND6 & $\mathrm{J}$ & $9,549-10,025$ & 477 & ATA & TAA & - & 2 \\
\hline CYTB & $\mathrm{J}$ & $10,030-11,151$ & 1,122 & ATT & TAA & - & 4 \\
\hline $\operatorname{trnS2}(U C N)$ & $\mathrm{J}$ & $11,151-11,214$ & 64 & - & - & TGA & -1 \\
\hline ND1 & $\mathrm{N}$ & $11,216-12,146$ & 939 & ATT & TAA & - & 1 \\
\hline $\operatorname{trn} L 2(C U N)$ & $\mathrm{N}$ & $12,147-12,214$ & 68 & - & - & TAG & 0 \\
\hline$r r n L$ & $\mathrm{~N}$ & $12,215-13,394$ & 1,180 & - & - & - & 0 \\
\hline $\operatorname{trn} V$ & $\mathrm{~N}$ & $13,395-13,454$ & 60 & - & - & TAC & 0 \\
\hline $\operatorname{rrnS}$ & $\mathrm{N}$ & $13,455-14,185$ & 731 & - & - & & 0 \\
\hline $\mathrm{A}+\mathrm{T}$-rich & & $14,148-14,313$ & 166 & - & - & - & 0 \\
\hline
\end{tabular}

2 
Table 3 (on next page)

Annotation of the Olidiana ritcheriina mitogenome. 


\begin{tabular}{llllllllll}
\hline \multicolumn{1}{c}{ Regions } & Size & A \% & $\begin{array}{l}\text { G } \\
\text { \% }\end{array}$ & T \% & C \% & A+T \% & G+C \% & $\begin{array}{l}\text { AT } \\
\text { skew }\end{array}$ & $\begin{array}{l}\text { GC } \\
\text { skew }\end{array}$ \\
\hline Whole genome & 15,166 & 44.6 & 8.5 & 33.4 & 13.5 & 78.0 & 22.0 & 0.144 & -0.227 \\
PCGs & 10,890 & 44.7 & 8.8 & 32.1 & 14.4 & 77.2 & 23.2 & 0.163 & -0.250 \\
tRNA genes & 1405 & 43.6 & 9.5 & 34.9 & 11.9 & 78.6 & 21.4 & 0.111 & -0.110 \\
rRNA genes & 1911 & 47.0 & 7.0 & 34.1 & 12.0 & 81.1 & 18.9 & 0.160 & -0.265 \\
Control region & 981 & 39.9 & 7.8 & 43.9 & 8.4 & 83.8 & 16.2 & -0.049 & -0.031 \\
\hline
\end{tabular}


Table 4 (on next page)

Substitution saturation tests for the four dataset. 
Table :

\begin{tabular}{|c|c|c|c|c|c|c|c|c|c|c|}
\hline $\begin{array}{l}\text { Data } \\
\text { set }\end{array}$ & $\begin{array}{l}\text { Observ } \\
\text { ed Iss }\end{array}$ & $\begin{array}{l}\text { Iss.cSy } \\
m^{\mathrm{a}}\end{array}$ & $\begin{array}{l}P s y \\
m^{\mathrm{b}}\end{array}$ & $\begin{array}{l}\text { Iss.cAsy } \\
m^{\mathrm{c}}\end{array}$ & $\begin{array}{l}\text { Pasy } \\
m^{\mathrm{d}}\end{array}$ & $\begin{array}{l}\text { Data } \\
\text { set }\end{array}$ & $\begin{array}{l}\text { Observ } \\
\text { ed Iss }\end{array}$ & $\begin{array}{l}\text { Iss.cSy } \\
m^{\mathrm{a}}\end{array}$ & $\begin{array}{l}P s y \\
m^{\mathrm{b}}\end{array}$ & $\begin{array}{l}\text { Iss.cAsy } \\
m^{\mathrm{c}}\end{array}$ \\
\hline P123 & 0.419 & 0.817 & $\begin{array}{l}0.00 \\
00\end{array}$ & 0.571 & $\begin{array}{l}0.00 \\
00\end{array}$ & $\begin{array}{l}\text { P123- } \\
\text { rR }\end{array}$ & 0.420 & 0.818 & $\begin{array}{l}0.00 \\
00\end{array}$ & 0.572 \\
\hline P12 & 0.296 & 0.814 & $\begin{array}{l}0.00 \\
00\end{array}$ & 0.570 & $\begin{array}{l}0.00 \\
00\end{array}$ & $\begin{array}{l}\text { P12- } \\
\text { rR }\end{array}$ & 0.320 & 0.816 & $\begin{array}{l}0.00 \\
00\end{array}$ & 0.571 \\
\hline
\end{tabular}

1

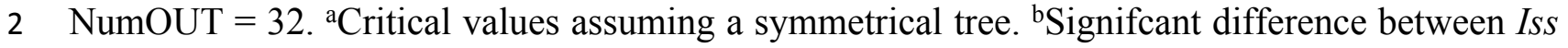
3 and Iss.cSym (two-tailed test). ${ }^{c}$ Critical values assuming an extreme asymmetrical tree.

4 dSignifcant difference between Iss and Iss.cAsym (two-tailed $t$-test). 